\title{
POLA ASUH DAN PEMBINAAN SOSIAL REMAJA PADA PONDOK PESANTREN
}

\author{
MUMU MUKHLISIN \\ Pascasarjana PMIPA, Universitas Indraprasta PGRI, Jakarta \\ e-mail: mumu.mukhlisin@gmail.com
}

\begin{abstract}
ABSTRAK
Pendidikan Pondok Pesantren (Pesantren) mulai banyak diminati oleh masyarakat sebagai wadah pendidikan formal maupun informal. Daya tarik utama pendidikan pesantren adalah tertanamnya budi pekerti dan ilmu agama yang tidak dapat diperoleh dalam pendidikan formal. Penerapan pembiasaan karakter Islami yang diterapkan dalam kehidupan sehari-hari santri (santri) di pondok pesantren tidak lepas dari peran Kyai, Nyai serta ustadz dan ustadzah. Pola asuh dan pengembangan sosial yang diterapkan pada siswa bertujuan untuk mengubah karakter siswa menjadi karakter yang berbudi luhur sesuai dengan konsep Islam. Pembiasaan karakter islami dilakukan melalui aktivitas keseharian santri di pondok pesantren. Penelitian dengan pendekatan teoritis ini mencoba menganalisis konsep pola asuh dan perkembangan sosial remaja yang diterapkan di pondok pesantren. Hasil penelitian ini menunjukkan bahwa Pola asuh di Pondok Pesantren Darunnajah menggunakan pola asuh demokratis. Peran Kyai dan Nyai sebagai suri tauladan dan pembimbing merupakan salah satu bentuk perwujudan karakter religius. Penerapan disiplin di Pondok Pesantren dilakukan dengan menggunakan pendekatan pola asuh yang demokratis dan bertanggung jawab.
\end{abstract}

Kata Kunci : pola asuh, pembinaan sosial, Pondok Pesantren, Karakter.

\section{ABSTRACT}

Islamic Boarding School education (Pesantren) began to be in great demand by the community as a place for formal and informal education. The main attraction of pesantren education is the embeded of character and religious knowledge which cannot be obtained in formal education. The application of Islamic character habituation applied to the daily life of students (santri) in Islamic boarding schools cannot be separated from the role of Kyai, Nyai as well as ustadz and ustadzah. The pattern of parenting and social development applied to students aims to change the students characters into virtuous characters in accordance with Islamic concepts. The habituation of Islamic character is carried out through the daily activities of students in Islamic boarding schools. This research with a theoretical approach tries to analyze the concept of parenting and social development of adolescents applied in Islamic boarding schools. The results of this study indicate that Parenting at Darunnajah Islamic Boarding School uses democratic parenting. The role of Kyai and Nyai as role models and mentors is a form of embodiment of religious characters. The application of discipline in the Islamic Boarding School did by using democratic and responsible parenting approach.

Keyword : parenting, social coaching, Islamic Boarding School, Character

\section{PENDAHULUAN}

Pondok pesantren merupakan salah satu tempat pendidikan tertua dalam sejarah pendidikan di Indonesia. Kuntowijoyo dalam Qomar (2005: 2) menyebutkan bahwa Pondok pesantren adalah suatu tempat yang tersedia untuk para santri dalam menerima pelajaranpelajaran agama Islam sekaligus tempat berkumpul dan tempat tinggalnya. Pada mulanya, pondok pesantren merupakan sebuah lembaga pendidikan non-formal yang dikonsentrasikan untuk menjadi sebuah tempat pembelajaran agama. Berbagai keilmuan agama di pelajari di pesantren, mulai dari tasawwuf, nahwu, shorof, tauhid, tajwid dan lain-lain. Kemudian, dalam perkembangannya, banyak pesantren yang juga membuka sekolah umum, mulai dari tingkat sekolah dasar hingga sekolah menengah. Perubahan ini tentunya juga di dukung oleh banyak pihak. Adalah Rabithah Ma'ahid Islamiyah (RMI) PBNU yang menggaungkan gerakan "Ayo 
Mondok". Gerakan ini mengajak masyarakat untuk memilihkan pesantren sebagai tempat pendidikan bagi anak-anak mereka. Selain untuk mendorong kepercayaan masyarakat terhadap pondok pesantren, di sisi lain gerakan dimaksudkan untuk mendorong tumbuhnya keilmuan islam.

Menurut Apandi (2017) ada empat manfaat anak yang menempuh pendidikan di pesantren, yaitu : 1) anak mendapatkan ilmu pendidikan umum dan agama, sehingga anak akan cerdas secara intelektual dan secara kepribadian, sosial, dan spiritual; 2) Anak berlatih hidup mandiri, mengelola pribadi dan menjadi pribadi yang tidak tergantung kepada orang tua; 3 ) Anak berlatih disiplin, karena berada di lingkungan pesantren artinya mengikuti tata tertib yang berlaku; 4) anak membangun mental yang kuat sebagai bekal kehidupan di masyarakat. Bahwasanya kesuksesan seseorang tidak hanya tergantung kepada kecerdasan intelektualnya (hard skill), juga memiliki mentalitas yang kuat.

Pola asuh dan pembinaan santri pada pondok pesantren dilaksanakan agar santri dapat beradaptasi dan mempunyai karakter yang di harapkan sesuai dengan tuntunan dalam ajaran agama islam. Diponegoro (2005) menyatakan selama di Pondok Pesantren para santri cenderung mengadopsi nilai-nilai Islam seperti persaudaraan (ukhuwah), persatuan (ittihad), tolong menolong (ta'awun), dan kepatuhan (tha'at) kepada Tuhan, Rasul, Ulama/Kyai, dan orang-orang yang diakui sebagai pemimpin. Persaudaraan, persatuan,dan tolong menolong adalah nilai-nilai yang membentuk dan memperkuat karakter kebersyukuran (gratitude), kebaikan hati.

Pembentukan karakter santri ini tentu tidak lepas dari cara pengasuhan dan pendidikan oleh Kyai dan Nyai sebagai pemimpin Pondok Pesantren yang membimbing santri selama berada di Pondok Pesantren. Jika dalam lingkungan asal, orang tua memegang peran utama dalam mengasuh dan membentu karakter anak, maka ketika anak kemudian masuk ke dalam lingkungan pesantren tugas ini diambil oleh oleh Kyai dan Nyai di lingkungan Pondok Pesantren. Pembiasaan yang dilakukan agar santri/santriwati bisa melepaskan kebiasaan buruk dari lingkungan asal dan menanamkan karakter baik sesuai dengan ajaran agama Islam.

Peran Kyai dan Nyai sebagai pemimpin keluarga menenpatkan dasar perilaku dan kebiasaan yang akan berlaku di lingkungan pesantren. Tugas ini selayaknya institusi pendidikan informal mempersiapkan santri menjadi anggota masyarakat yang baik. Pola asuh ini akan membentuk sisi kognitif, emosi dan perkembangan agama.

Di sisi lain, tidak bisa dipungkiri bahwa santri berangkat dari berbagai jenis kondisi latar belakang yang tentunya majemuk. Modal awal karakter santri tentu ditentukan oleh pola pengasuhan dalam keluarganya. Anak yang dididik dalam keluarga yang beriman melihat orang tua rukun dan damai serta penuh menjalankan ibadah kepada Tuhan maka yang akan masuk dalam pribadi anak adalah apa yang dialaminya itu, yakni ketentraman hati, kedamaiaan dan kecintaan kepada Tuhan, sedangkan anak yang diasuh tanpa tanggung jawab moral yang tinggi dari orang tua akan banyak mengalami kesulitan bahkan cenderung berperilaku agresif seperti merusak, melanggar peraturan, dan perilaku lain yang dapat merugikan dirinya sendiri dan orang lain. Lingkungan keluarga yang seharusnya merupakan lingkungan pertama anak mendapatkan pendidikan agama, tidak jarang malah menimbulkan trauma pada diri anak. Hal ini disebabkan karena orang tua tidak memiliki cukup pemahaman dan ilmu tentang bagaimana memberikan pembiasaan keagamaan kepada anak. Orang tua memberikan pembiasaan sholat atau puasa dengan menerapkan ancaman dan tekanan. Hal ini tentu membuat anak merasa terpaksa dan menjadi enggan melakukan ibadah ketika lepas dari pengawasan orang tua.

Sebagai bentuk penyelamatan dan ketidaksanggupan orangtua mendidik anaknya, tidak jarang orang tua kemudian memilih memasukkan anak ke pondok pesantren. Jika hal ini dilakukan, maka siswa akan merasa bahwa pesantren bukan lagi menjadi tempat idaman menuntut ilmu, namun sebagai tempat hukuman karena tidak mengikuti norma hidup seperti yang diharapkan orang tua. Kesan awal ini juga menjadi masalah tersendiri bagi pengasuh pondok pesantren dalam membimbing anak melakukan pembiasaan kepada santri untuk membentuk karakter islami. Dalam sebuah penelitiannya, Susanto (2017) menyebutan beberapa 
prilaku negatif santri yang tidak sesuai dengan budaya pesantren antara lain tidak mengenakan jilbab dalam kehidupan keseharian di luar pesantren, meminum alkohol dan sejenisnya, memakai narkoba, mencuri barang, mengedepankan ego, bahkan meninggalkan puasa dan sholat. Prilaku bawaan inilah yang kemudian diusahakan untuk dirubah melalui pembiasaan karakter Islami di pondok pesantren.

Berangkat dari fenomena ini, penulis berusaha menelusuri bagaimana pola asuh dan pembinaan sosial remaja pada santri yang dilakukan oleh pondok pesantren dalam menciptakan suasana pondok pesantren yang agamis.

\section{METODE PENELITIAN}

Penelitian ini menggunakan metode penelitian Pustaka (library research). Menurut Zed (2008:3), riset kepustakaan atau sering juga disebut studi pustaka, ialah serangkaian kegiatan yang berkenaan dengan metode pengumpulan data pustaka, membaca dan mencatat serta mengolah bahan penelitian. Mahmud (2011:31) menjelaskan bahwa penelitian kepustakaan yaitu jenis penelitian yang dilakukan dengan membaca buku-buku atau majalah dan sumber data lainnya untuk menghimpun data dari berbagai literatur, baik perpustakaan maupun di tempat-tempat lain.

Dalam metode penelitian ini, informasi dan bahan literatur yang dikumpulkan dan digunakan berasal dari study dokumen, baik dari buku maupun jurnal, makalah, artikel maupun jurnal dari penelitian yang dilakukan terlebih dahulu. Penelitian ini secara sistematis dilakukan dengan mengumpulkan, mengolah, dan menyimpulkan data dengan menggunakan kajian pustaka untuk memberikan informasi yang benar dan tepat yang digunakan untuk menjawab dari permasalahan yang diperoleh.

Alasan yang mendasari penulis untuk melakukan studi pustaka yaitu, 1) karena sumber data tidak hanya bisa diperoleh dari penelitian langsung di lapangan. Adakalanya sumber data bisa diperoleh dari pengumpulan dokumen dan penelusuran pustaka; 2) studi pustaka dapat menterjemahkan gejala maupun kejadian yang terjadi secara general; dan 3) karena studi pustaka dapat menjawab persoalan penelitinya. (Zed, 2008)

\section{HASIL DAN PEMBAHASAN}

\section{Hasil Penelitian}

Berdasarkan hasil study pustaka dari berbagai referensi dan artikel penelitian terdahulu berkaitan dengan pola asuh dan pembinaan sosial remaja pada pondok pesantren, berikut temuan yang berkaitan dengan pola asuh dan pembinaan sosial santri di pondok pesantren.

\begin{tabular}{|c|c|c|c|}
\hline No & Artikel & Temuan & Refleksi \\
\hline 1 & $\begin{array}{l}\text { PONDOK } \\
\text { PESANTREN : } \\
\text { Lembaga } \\
\text { Pendidikan } \\
\text { Pembentukan } \\
\text { Karakter (Iman } \\
\text { Syafe'i, 2017) }\end{array}$ & $\begin{array}{l}\text { Keberadaan pesantren merupakan patner } \\
\text { yang ideal bagi institusi pemerintah untuk } \\
\text { bersama-sama meningkatkan mutu } \\
\text { pendidikan yang ada sebagai basis bagi } \\
\text { pelaksanaan } \\
\text { transformasi sosial melalui penyediaan } \\
\text { sumber daya manusia yang qualified dan } \\
\text { berakhlakul } \\
\text { karimah. Terlebih lagi, proses transformasi } \\
\text { sosial di era otonomi, mensyaratkan daerah } \\
\text { lebih }\end{array}$ & $\begin{array}{l}\text { Pondok Pesantren dapat } \\
\text { mempunyai peran ganda. } \\
\text { Sebagai lembaga } \\
\text { pendidikan formal yang } \\
\text { berperan serta dalam } \\
\text { meningkatkan mutu } \\
\text { pendidikan. Di sisi lain, } \\
\text { dalam pendidikan } \\
\text { informal, pesantren } \\
\text { berperan aktif } \\
\text { membentuk karakter } \\
\text { manusia yang } \\
\text { berakhlakul karimah. }\end{array}$ \\
\hline
\end{tabular}




\begin{tabular}{|c|c|c|c|}
\hline & & $\begin{array}{l}\text { peka menggali potensi lokal dan kebutuhan } \\
\text { masyarakatnya sehingga kemampuan yang } \\
\text { ada } \\
\text { dalam masyarakat dapat dioptimalkan. }\end{array}$ & \\
\hline 2 & $\begin{array}{l}\text { Penerapan Pola } \\
\text { Asuh Terhadap } \\
\text { Santri di Pondok } \\
\text { Pesantren Al- } \\
\text { Amalul Khair } \\
\text { Palembang (Ali, } \\
\text { Kemas MAs'ud., } \\
\text { Imtihana, Aida, } \\
\text { Islamil. Fajri, } \\
\text { Zaini, Herman. : } \\
\text { 2017) }\end{array}$ & $\begin{array}{l}\text { Pesantren menerapkan aturan yang harus } \\
\text { ditaati oleh setiap santri, apabila terjadi } \\
\text { pelanggaran, santri akan mendapatkan } \\
\text { hukuman dari riang sampai ke berat, seperti } \\
\text { membersihkan pekarangan di sekitar } \\
\text { Pesantren, dipukul pada bagian telapak } \\
\text { kaki, dan dijemur dalam waktu tertentu. } \\
\text { Disiplin dilakukan melihat situasi dan } \\
\text { kondisi, adakala diperketat dan di hari lain } \\
\text { diperlonggar. Kyai selalu dijadikan figur } \\
\text { bagi santri. Oleh karena itu, mereka sering } \\
\text { mengadakan berkomunikasi dengan Kyai, } \\
\text { sedangkan Kyai merespon semua keluhan } \\
\text { santri. Di samping itu, Kyai selalu } \\
\text { memberikan wejangan kepada santri. Kyai } \\
\text { selalu memberikan kebebasan kepada para } \\
\text { santri untuk menumbuhkem-bangkan bakat } \\
\text { mereka, jika mereka mendapatkan prestasi } \\
\text { akan diberi penghargaan/apresiasi oleh } \\
\text { Kyai. Kyai selalu membangkitkan } \\
\text { semangat para santri agar tidak terlalu } \\
\text { bergantung kepada seseorang dan } \\
\text { menekankan agar santri dapat hidup } \\
\text { mandiri. }\end{array}$ & $\begin{array}{l}\text { Pola Asuh yang di } \\
\text { terapkan di pondok } \\
\text { pesantren umumnya } \\
\text { terpusat pada sosok Kyai } \\
\text { yang menjadi figur } \\
\text { panutan. Meski } \\
\text { demikian, pola demokrtis } \\
\text { juga tampak pada } \\
\text { kebebasan santri } \\
\text { mengembangkan } \\
\text { bakat/prestasi agar santri } \\
\text { dapat hidup mandiri. } \\
\text { Dalam penegakan } \\
\text { disiplin, pondok } \\
\text { pesantren menggunakan } \\
\text { system disiplin dan } \\
\text { punishment dengan } \\
\text { tingkat yang berbeda } \\
\text { didasarkan pada jenis } \\
\text { aturan yang dilanggar. }\end{array}$ \\
\hline 3 & $\begin{array}{l}\text { Pola Asuh dan } \\
\text { Pembentukan } \\
\text { Karakter Santri di } \\
\text { Pondok Pesantren } \\
\text { ( Ina Ambarwati, } \\
\text { 2017) }\end{array}$ & $\begin{array}{l}\text { Pola Asuh yang di terapkan di pondok } \\
\text { pesantren Nurul Huda Desa Mandiangin } \\
\text { Kecamatan Mandiangin Kabupaten } \\
\text { Sarolangun ada 2, tipe otoriter dengan Kyai } \\
\text { sebagai Pengendali semua aturan yang ada, } \\
\text { disertai sanksi untuk pelanggaran peraturan. } \\
\text { Sedangkan Tipe demokratis terlihat dari } \\
\text { adanya musyawarah dann menyetujio } \\
\text { pelaksanaan lehoatan dan pengambilan } \\
\text { musyawarah keputusan yag dilakukan. } \\
\text { Hasil pola asuh yang doterapkan adalah } \\
\text { terbentuknya karakter jujur dan disiplin. } \\
\text { Meski demikian masih tampak pada } \\
\text { beberapa santri karakter ini tidak muncul, } \\
\text { sehingga membuktikan bahwa pola asuh } \\
\text { yang diterapkan belum sepenuhnya mampu } \\
\text { membentuk karakter santri. }\end{array}$ & $\begin{array}{l}\text { Yang Nampak pada pola } \\
\text { asuh adalah pola ototriter } \\
\text { dan demokratis pada saat } \\
\text { yang bersamaan. } \\
\text { Sedangkan pola asuh } \\
\text { yang diterapkan untuk } \\
\text { pembentukan karakter } \\
\text { memiliki factor pribadi } \\
\text { santri, dimana } \\
\text { pembiasaan bisa } \\
\text { dilakukan jika santri juga } \\
\text { mau membantun } \\
\text { karakternya sendiri. Jika } \\
\text { ada penolakan dari santri } \\
\text { dalam pembentukan } \\
\text { karakter, maka hal ini } \\
\text { merupakan tantangan } \\
\text { bagi pesantren. }\end{array}$ \\
\hline 4 & $\begin{array}{l}\text { Strategi } \\
\text { Pembinaan } \\
\text { Akhlak di Pondok }\end{array}$ & $\begin{array}{l}\text { Strategi pembinaan yang dilakukan di } \\
\text { Pondok Pesantren Internasional Dea } \\
\text { Malela yaitu dengan menerapkan }\end{array}$ & $\begin{array}{l}\text { Dalam melakukan } \\
\text { pembiasaan akhlak baik, } \\
\text { di pesantren dilakukan }\end{array}$ \\
\hline
\end{tabular}




\begin{tabular}{|c|c|c|c|}
\hline & $\begin{array}{l}\text { Pesantren } \\
\text { Internasional Dea } \\
\text { Malela. (Sriyatun } \\
\text { dkk : 2020) }\end{array}$ & $\begin{array}{l}\text { kedisiplinan, keteladanan, kesederhanaan, } \\
\text { pembiasaan dan memperbanyak kegiatan } \\
\text { kegiatan yang bisa memaksimalkan potensi } \\
\text { dari setiap santri. Untuk bidang } \\
\text { kepesantrenan PPM Dea Malela memiliki } \\
\text { program-program wajib seperti Qiyamul- } \\
\text { Lail, One Day One Verse, Literasi, Sholat } \\
\text { Dhuha, Muwajjah (belajar malam), } \\
\text { Ma'tsuroh (berdoa bersama sebelum tidur), } \\
\text { pengabsenan, belajar kosakata Bahasa Arab } \\
\text { dan Inggris, Baca al-Qur'an, Halaqoh } \\
\text { bersama Wali Asuh, pelatihan Public } \\
\text { Speaking atau pidato. Dari keseluruhan } \\
\text { kegiatan ini, santri menyatakan merasakan } \\
\text { perubahan akhlak dalam diri mereka, } \\
\text { namun setiap santri memiliki nilai } \\
\text { perubahan akhlak yang berbeda-beda. Di } \\
\text { sisi lain, ada hambatan, yakni pada santri } \\
\text { yang tida serius mengikuti kegiatan serta } \\
\text { penggunaan ponsel yang tidak di batasi } \\
\text { sehingga membawa pengaruh buruk. }\end{array}$ & $\begin{array}{l}\text { dalam bentuk kegiatan } \\
\text { rutin pesantren maupun } \\
\text { kegiatan tambahan untuk } \\
\text { peningkatan } \\
\text { kompetensi/keahlian. } \\
\text { Motivasi dari dalam diri } \\
\text { santri sangat dibutuhkan } \\
\text { agar proses pembinaan } \\
\text { akhlak dan pembiasaan } \\
\text { prilaku baik, bisa } \\
\text { dijadikan karakter tetap } \\
\text { santri. }\end{array}$ \\
\hline 5 & $\begin{array}{l}\text { Pola Pembinaan } \\
\text { Santri dalam } \\
\text { Pengendalian } \\
\text { Prilaku } \\
\text { Menyimpang di } \\
\text { Pondok Pesantren } \\
\text { ar-Risalah Kota } \\
\text { Jember (Suryadi } \\
\text { \& Maslahatun } \\
\text { Nikmah : 2019) }\end{array}$ & $\begin{array}{l}\text { Faktor penyebab prilaku menyimpang di } \\
\text { pondok pesantren ar-Risalah kota jember } \\
\text { yaitu : 1) lingkungan keluarga (broken } \\
\text { home, ekonomi lemah, kurang kasih } \\
\text { sayang). 2) faktor teman sebaya, 3) kondisi } \\
\text { lingkungan pesantren (pendidikan yang } \\
\text { kurang menananmkan tingkah laku, } \\
\text { menurunnya wibawa guru/ustadz, } \\
\text { pengawasan yang kurang, dan ketidak } \\
\text { pahaman guru.ustadz dalam menangani } \\
\text { masalah remana baik secara sosial, } \\
\text { psikologis maupun pedagogik) } \\
\text { Pola pembinaan pengendalian prilaku } \\
\text { menyimpang terdiri dari tiga pola : pola } \\
\text { prefentif (penncegahan : sholat tahajud, } \\
\text { puasa, mengaji kitab), represif } \\
\text { (penanganan : penerapan sanksi) dan } \\
\text { kuratif (hukuman : tidak naik } \\
\text { kelas/dikembalikan ke orang tua) }\end{array}$ & $\begin{array}{l}\text { Faktor prilaku } \\
\text { menyimpang, bisa } \\
\text { berasal dari lingkungan } \\
\text { asal santri (keluarga) } \\
\text { maupun interaksi di } \\
\text { pesantren (terbawa } \\
\text { teman). Dalam } \\
\text { penanganan pelanggaran, } \\
\text { ada hal yang perlu } \\
\text { dilakukan secara } \\
\text { bertahap, yakni preventif, } \\
\text { represif dan kuratif. }\end{array}$ \\
\hline
\end{tabular}

\section{Pembahasan}

1. Pola asuh

Anak terlahir dengan katakter murni dan bersih. Dalam perjalanan kehidupannya, orang tua ataupun lingkungan terdekat akan memberikan warna pada karakter anak. Hal ini berkaitan erat dengan cara pengasuhan anak atau yang dikenal dengan istilah pola asuh. Hidayat (2019) menyatakan bahwa pola asuh merupakan sistem atau cara pendidikan, pembinaan yang diberikan oleh seseorang kepada orang lain. Santrock dalam Hidayat (2002) menyatakan bahwa pola asuh adalah cara atau metode pengasuhan yang digunakan oleh orang tua agar anak-anaknya dapat tumbuh menjadi individu-individu yang dewasa 
secara sosial. Sedangkan Gunarsa (1990), mengungkapkan bahwa pola asuh adalah suatu gaya mendidik yang dilakukan oleh orang tua untuk membimbing dan mendidik anakanaknya dalam proses interaksi yang bertujuan memperoleh suatu perilaku yang diinginkan.

Pola asuh dari lingkungan terdekat memberikan cetak biru pada anak tentang bagaimana bersikap dan merespon sebuah situasi. Jenis pola asuh sendiri bervariasi. Menurut Hidayat (2019) ada empat jenis pola asuh, yakni:

a. Pola asuh demokrasi

Pola asuh demikrasi ditandai dengan orang tua yang memberikan kebebasan yang memadai pada anaknya tetapi memiliki standar perilaku yang jelas. Mereka memberikan alasan yang kelas dan mau mendengarkan anaknya tetapi juga tidak segan untuk menetapkan beberapa perilaku yang tegas dalam menentukan batasan. Manfaat dari pola asuh ini adalah: 1) anak akan belajar menghargai, menghormati pendapat orang lain; 2) anak selalu memberi perhatian kepada sesamanya; 3) anak akan berusaha membangun kerjasama dengan orang lain

b. Pola asuh otoriter

Pola asuh ini cukup ketat dengan apa yang mereka harapkan dari anaknya dan hukuman dan perilaku anak yang kurang baik. Peraturan diterapkan secara kaku dan seringkali tidak dijelaskan secara memadai dan kurang memahami serta mendengarkan kemauan anaknya. Penekanan pola asuh ini adalah ketaatan tanpa bertanya dan menghargai tingkat kekuasaan. Disiplin pada rumah tangga ini cenderung kasar dan banyak hukuman. Dampak dari pola asuh ini adalah: 1) anak tertekan secara psikis dan fisik; 2) hilang semangat dan selalu menyalahkan diri sendiri; 3) tidak memiliki inisiatif, ide-ide cemerlang karena selalu ditekan; 4) tidak berani berpendapat dan menentukan pilihan.

c. Pola asuh tanpa kendali

Dalam pola asuh ini orangtua membiarkan anaknya untuk menampilkan dirinya dan tidak tidak membuat aturan yang jelas serta kejelasan tentang perilaku yang mereka harapkan. Mereka seringkali menerima/tidak perduli dengan perilaku yang buruk.

Hubungan dengan anak mereka adalah hangat dan menerima. Pada saat meenntukan batasan, mereka mencoba untuk memberikan alasan kepada anaknya dan tidak mengunakan kekuasaan untuk mencapai keinginan mereka. Dampak dari pola asuh ini adalah: 1) anak akan bertindak sekehendak hati; 2) tidak dapat mengendalikan dirinya; 3) hidup bebas tanpa aturan; 4) selalu memaksakan kehendak dan egois; 5) selalu ragu membedakan mana yang benar dan mana yang salah;

d. Pola asuh yang berlebihan

Dalam hal ini semangat untuk memberikan perlakuan dan perlindungan yang baik, namu berlebihan caranya akan menimbulkan masalah karena anak-anak akan memiliki mentalitas yang lemah bila menghadapi tantangan dan kesulitan Dampak dari pola asuh ini adalah: 1) menghilangkan kesempatan pada anak untuk bersosialisasi; 2) anak akan selalu merasa ketakutan dan tidak memiliki kemandirian; 3) kurang bertanggung jawab dan tidak bisa mengambil keputusan; 4) selalu ragu-ragu, mudah cemas dan penakut; 5) kurang percaya diri, sulit membangun relasi, dan tida berani menghadapi kenyataan.

Menurut Shohcib (2010: 36) konsep pengasuhan adalah upaya yang digunakan untuk memahami, menginterprestasi dan menemukan makna-makna yang terkandung dalam mengembangkan dasar-dasar nilai anak. Pengupayaan dilakukan melalui pelatihan, pembiasaan dan penyadaran kepada anak dan di aktualisasikan melalui perilaku orang tua yang taat moral, terutama pada saat pertemuan dengan anak; menata komunikasi secara verbal maupun nonverbal; kontrol terhadap perilaku anak, serta penataan lingkungan internal dan eksternal. 
Masing-masing pola asuh yang dipilih oleh orang tua akan membentuk karakter anak di masa depan. Sedangkan kondisi yang tercipta dari lingkungan sekitar menjadi stimulus bagi anak untuk merespon situasi berdasarkan pemahaman dan pengetahuan yang didapatkan. Hal ini tentu saja dipengaruhi oleh pemilihan pola asuh orang tua kepada anaknya.

\section{Pembinaan Sosial}

Mangun Hardjana (1986) menyatakan bahwa pembinaan adalah terjemahan dari kata training, yang mengartikan pembinaan sebagai latihan, pendidikan, pembinaan yang ditekankan pada pengembangan sikap, kecakapan dan kemampuan. lebih lanjut dikatakan bahwa pembinaan membantu orang untuk mengenali hambatan-hambatan baik yang ada di dalam situasi hidup dengan melihat segi-segi positif dan negatifnya, serta menemukan caracara pemecahannya.

Pembinaan sosial adalah latihan, pendidikan, pembinaan yang ditekankan pada perubahan perilaku sosial sehingga mencapai sikap dan kecakapan sosial yang diharapkan. Terutama dalam hidup berkelompok/bermasyarakat. Hal ini erat kaitannya dengan pembangunan karakter positif dalam menghadapi situasi hidup bermasyarakat.

Karakter seseorang bisa dirubah dengan pembinaan intensif dan didukung oleh lingkungan. Karakter seseorang bisa dirubah dengan pembinaan sosial atas dasar mengikuti karakter yang dibuat dalam sebuah komunitas. Mungkin pada awalnya perubahan ini terkesan dipaksakan, namun dengan pembiasaan, karakter positif baru yang terbentuk dapat menyelaraskan dengan lingkungan baru yang kondusif.

\section{Remaja}

Santrrock dalam Hidayat (2019) menyatakan bahwa masa remaja atau adolescene diartikan sebagai masa perkembangan transisi antara masa anak dan masa dewasa yang mencakup perubahan biologis, kognitif dan sosial-emosional.

Batasan usia remaja yang umum digunakan oleh para ahli adalah antara 12 hingga 21 tahun. Rentang waktu usia remaja ini biasanya dibedakan atas tiga, yaitu 12-15 tahun adalah masa remaja awal, 15-18 tahun adalah masa remaja pertengahan, dan 18-21 tahun adalah masa remaja akhir.

Lebih lanjut, Soetjiningsih (2010) memberikan penjelasan bahwa berdasarkan proses penyesuaian menuju kedewasaan, ada 3 tahap perkembangan remaja, yaitu :

a. Remaja awal (Early adolescent) umur 12-15 tahun

Seorang remaja untuk tahap ini akan terjadi perubahan-perubahan yang terjadi pada tubuhnya sendiri dan yang akan menyertai perubahanperubahan itu, mereka pengembangkan pikiran-pikiran baru sehingga, cepat tertarik pada lawan jenis, mudah terangsang secara erotis, dengan dipegang bahunya saja oleh lawan jenis ia sudah akan berfantasi erotik.

b. Remaja madya (middle adolescent) berumur 15-18 tahun

Tahap ini remaja membutuhkan kawan-kawan, remaja senang jika banyak teman yang mengakuinya. Ada kecenderungan mencintai pada diri sendiri, dengan menyukai teman-teman yang sama dengan dirinya, selain itu ia berada dalam kondisi kebingungan karena tidak tahu memilih yang mana peka atau tidak peduli, ramai-ramai atau sendiri, optimis atau pesimistis, idealitas atau materialis, dan sebagainya.

c. Remaja akhir (late adolescent) berumur 18-21 tahun

Tahap ini merupakan dimana masa konsolidasi menuju periode dewasa dan ditandai dengan pencapaian 5 hal yaitu: 1) minat makin yang akan mantap terhadap fungsi intelek; 2) egonya akan mencari kesempatan untuk bersatu dengan orang lain dan dalam pengalaman-penglaman baru; 3) terbentuk identitas seksual yang tidak berubah lagi; 4) egosentrisme (terlalu mencari perhatian pada diri sendiri) diganti dengan 
keseimbangan dan kepentingan diri sendiri dengan orang lain; 5) tumbuh "dinding" yang memisahkan diri pribadinya (private self); 6) masyarakat umum

\section{Pondok Pesantren}

a. Sejarah Pondok Pesantren

Dalam sejarahnya, pondok pesantren merupakan lembaga pendidikan rakyat yang sudah berlangsung sejak lama. Pada pondok pesantren pendidikan ditekankan pada aspek keagamaan untuk menjadi role model bagi masyarakat. Perkembangan pendidikan pesantren yang pesat selaras dengan semangat dan kepribadian bangsa Indonesia yang mayoritas beragama islam, nampaknya wajar menjadikan jumlah pesantren tumbuh secara signifikan. Pesantren diakui sebagai lembaga yang sangat berjasa dalam membentuk masyarakat Indonesia yang religius hampir 90\% penduduk Indonesia dan mempertahankannya sampai sekarang hingga menjadi negara berpenduduk muslim terbanyak.

Kata pesantren atau santri sendiri berasal dari bahasa Tamil yang berarti guru mengaji. Namun, ada juga yang menyebutkan bahwa kata ini berasal dari bahasa India, yaitu shastri yang berasal dari kata shastra yang berarti buku-buku suci, buku-buku agama, atau buku-buku tentang ilmu pengetahuan.

Menurut Shihab (2002), Syaikh Maulāna Mālik Ibrāhīm atau Sunan Gresik merupakan orang pertama yang membangun lembaga pengajian yang merupakan cikal bakal berdirinya pesantren sebagai tempat mendidik dan menggembleng para santri. Tujuannya adalah agar para santri menjadi juru dakwah yang mahir sebelum mereka diterjunkan langsung di masyarakat luas.

Keberadaan pesantren di Indonesia pertama kali ditemukan pada karya-karya Jawa klasik seperti Serat Cabolek dan Serat Centhini yang berasal dari abad ke-16. dari sumber inilah diketahui bahwa pesantren mengajarkan berbagai kitab islam klasik dalam bidang fikih, teologi, dan tasawuf, serta menjadi pusat penyiaran agama islam. Berdasarkan data Departemen Agama tahun 1984-1985, jumlah pesantren di abad ke16 sebanyak 613 buah. Pesantren kemudian berkembang di dareah sepanjang pantai utara jawa, mulai dri diri (gresik), Ampel (Surabaya), Bonang (Tuban), Kudus, Lasem hingga Cirebon.

Istilah Pondok Pesantren sendiri merupakan rangkaian kata yang terdiri dari pondok dan pesantren. Kata pondok (kamar, gubuk, rumah kecil) yang dipakai dalam bahasa Indonesia dengan menekankan kesederhanaan bangunannya. Ada pula kemungkinan bahwa kata pondok berasal dari bahasa arab "fundūk" yang berarti ruang tempat tidur, wisma atau hotel sederhana. Pada umumnya pondok memang merupakan tempat penampungan sederhana bagi para pelajar yang jauh dari tempat asalnya, sedangkan kata pesantren berasal dari kata dasar "santri" yang dibubuhi awalan "pe" dan akhiran "an" yang berarti tempat tinggal para santri.

Di tahun 1920-an pesantren-pesantren di Jawa Timur seperti Pesantren Tebuireng, dan Pesantren Singosari mulai mengajarkan pelajaran umum seperti bahasa Indonesia, Bahasa Belanda, berhitung, ilmu bumi, dan sejarah. Pada masa penjajahan Belanda, pesantren berkembang dengan pesat. Pesantren ini ada yang memiliki kekhususan sehingga berbeda dengan pesantren lainnya. Ada yang khusus mengajarkan ilmu hadis dan fikih, ilmu bahasa Arab, ilmu tafsir, tasawuf, dan lain-lain.

Kemudian pesantren memasukkan sistem madrasah. Dalam sistem ini jenjangjenjang pendudukan terbagi menjadi ibtidaiah, tsanawiyah, dan aliah. Sistem madrasah ini mendorong perkembangan pesantren sehingga jumlahnya meningkat pesat.Pada tahun 1958/1959 lahir Madrasah Wajib Belajar yang memiliki hak dan kewajiban seperti sekolah negeri. Selanjutnya, di tahun 1965, berdasarkan rumusan Seminar Pondok Pesantren di Yogyakarta, disepakati perlunya memasukkan pelajaran keterampilan seperti pertanian, pertukangan, dan lain-lain di pondok pesantren. 
Pada masa Orde Baru, pemerintah melakukan pembinaan terhadap pesantren melalui Proyek Pembangunan Lima Tahun (Pelita). Dana pembinaan pesantren diperoleh dari pemerintahan terkait, dari pemerintahan pusat hingga daerah. Tahun 1975, muncul gagasan untuk mengembangkan pondok pesantren dengan model baru. Lahirlah Pondok Karya Pembangunan, Pondok Modern, Islamic Center, dan Pondok Pesantren Pembangunan. Akan tetapi pondok pesantren ini mengalami kesulitan dalam pembinaan karena tidak adanya Kyai yang karismatik yang bisa memberi bimbingan dan teladan pada santrinya. Kemudian banyak pesantren yang mendirikan sekolah umum dengan kurikulum sekolah umum yang ditetapkan oleh pemerintah. Bahkan, pada Surat Keputusan Bersama Menteri Agama, Menteri Dalam Negeri, Menteri Pendidikan dan Kebudayaan No 03 tahun 1975, menetapkan mata pelajaran umum sekurang-kurangnya sebanyak 70 persen dari seluruh kurikulum madrasah. Banyak juga madrasah yang mendirikan perguruan tinggi seperti pesantren AS-Syafi'iyah dan pesantren at-Tahiriyah.

Pada tahun 2020 terbit peraturan perihal pendirian pondok pesantren diatur oleh Kementrian Agama. Masyarakat yang hendak mengajukan izin operasional pondok pesantren baik melalui yayasan maupun badan hukum lainnya mengajukan ke Kantor Kementerian Agama Kabupaten/Kota setempat dengan memenuhi persyaratan yang sudah ditentukan. Peraturan Menteri Agama (PMA) tentang pesantren yang merupakan turunan dari Undang-Undang No 18 Tahun 2019. Direktur Pendidikan Diniyah dan Pondok Pesantren Ditjen Pendidikan Islam Kemenag, merinci tiga jenis pesantren. Pertama, pesantren yang menyelenggarakan pendidikan dalam bentuk pengkajian kitab kuning. Kedua, pesantren yang menyelenggarakan pendidikan dalam bentuk Dirasah Islamiah dengan pola pendidikan Muallimin. Ketiga, pesantren yang menyelenggarakan pendidikan dalam bentuk lain yang terintegrasi dengan pendidikan umum. Ketiga jenis pesantren itu dapat didirikan perorangan, yayasan, ormas Islam, atau masyarakat.

Keberadaan pesantren dalam menjadi sumber ilmu kian kompleks karena menjadi sekolah sekaligus tempat tinggal dimana santri berinterkasi dan mengamalkan pelajaran karakter yang diajarkan. Menurut Usman (2013) pentingnya pesantren sebagai sebuah totalitas lingkungan pendidikan dalam makna dan nuansanya secara menyeluruh. Pesantren bisa juga dikatakan sebagai laboratorium kehidupan, tempat para santri belajar hidup dan bermasyarakat dalam berbagai segi dan aspeknya.

Dari pemaparan di atas, bisa diambil kesimpulan bahwa pesantren merupakan sebuah lembaga pendidikan yang menekankan pada pendidikan agama dan pembentukan karakter santri sesuai dengan ajaran agama Islam

b. Tujuan dan fungsi pondok pesantren

Tujuan didirikannya pesantren tak lepas dari faktor pendidikan itu sendiri. Dirjen Kelembagaan Agama Islam dari departemen Agama RI menyebutkan bahwa pada dasarnya pesantren sebagai lembaga pendidikan islam, tidak memiliki tujuan yang formal tertuang dalam teks tertulis. Namun hal itu bukan berarti pesantren tidak memiliki tujaun, setiap lembaga pendidikan yang melakukan suatu proses pendidikan, sudah pasti memiliki tujuan-tujuan yang diharapkan dapat dicapai, yang membedakan hanya apakah tujuan-tujuan tersebut tertuang secara formal dalam teks atau hanya berupa konsep-konsep yang tersimpan dalam fikiran pendidik. Hal itu tergantung dari kebijakan lembaga yang bersangkutan.

Menurut Mastuhu (1994) bahwa tujuan pendidikan pesantren adalah menciptakan dan menggambarkan kepribadian muslim yaitu kepribadian yang beriman dan bertaqwa kepada tuhan, berakhlak mulia, bermanfaat bagi masyarakat atau khidmat kepada mesyarakat dengan jalan menjadi kaula atau abdi masyarakat yang diharapkan seperti kepribadian rasul yaitu pelayan masyarakat sebagaimana kepribadian Nabi Muhamad SAW, mampu berdiri sendiri, bebas dan teguh dalam kepribadian, 
menyebabkan agama atau menegakkan islam dan kejayaan umat ditengah-tengah masyarakat (Izza Islam wa al-muslimin) dan mencintai ilmu dalam rangka mengembangkan kepribadian manusia. Arifin (2010) menjelaskan bahwa tujuan pendidikan Islam tidak lain adalah tujuan yang merealisasi idealitas Islami. Sedang idealitas Islami itu sendiri pada hakikatnya adalah mengandung nilai perilaku manusia yang didasari oleh iman dan takwa keapada Allah sebagai sumber kekuasaan mutlak yang harus ditaati.

Ma'shum (2005: 23) mengatakan fungsi pesantren mencakup 3 aspek yaitufungsi religious, sosial, dan edukasi. Lain halnya Azra dalam Nata (2001) yang menyebutkan bahwa pesantren memiliki tiga fungsi, yaitu transmisi dan transfer ilmuilmu Islam, pemeliharaan tradisi Islam, dan reproduksi ulama.

Damopolii (2011) menyebutkan bahwa peasntren memiliki lima fungsi, yaitu: 1) pesantren berfungsi sebagai lembaga pendidikan. Seperti diselanggarakannya pendidikan formal kesekolahan (SLTP/SMU) dan kepesantrenan; 2) pesantren berfungsi sebagai lembaga sosial. Fungsi ini ditujukan kepada masyarakat kampus pesantren itu sendiri, peserta didik, Pembina maupun pengelolanya; 3) pesantren berfungsi sebagai lembaga penyiar agama yang dicerminkan oleh keberadaan masjid di dalam kampus pesantren; 4) pesatren berfungsi sebagai reproduksi ulama yang dicerminkan oleh adanya lembaga kepesantrenan; 5) pesantren berfungsi sebagai pelestari tradisi Islam. Hal ini ditunjukkan dengan adanya perhatian yang besar dari lembaga pesantren untuk menggarap bidang keagamaan.

Berdasarkan fungsi yang dipaparkan di atas dapat di simpulkan bahwa pada umunya fungsi pesantren adalah sebagai lembaga yang mengembangkan pengetahuan dalam segi pendidikan, sosial dan budaya yang memberikan penekanan pada pengembangan agama Islam.

c. Komponen Pondok pesantren

Menurut Qomar (2005: 19-22) unsur-unsur pondok pesantren ada lima yaitu :

1) Kyai

Kyai merupakan elemen yang paling esensial dari suatu pesantren. Bahkan seringkali Kyai merupakan pendiri sebuah pesantren. Sudah sewajarnya bahwa pertumbuhan suatu pesantren semata-mata bergantung kepada kemampuan pribadi kyainya.

Kyai dipandang sebagai sosok yang memiliki keluasan pengetahuan mengenai agama Islam, memahami keagungan alam dan memiliki kedudukan yang luhur. Zamakhsyari menyebutkan asal-usulnya perkataan kyai dalam bahasa jawa dipakai untuk tiga jenis gelar yang saling berbeda, antara lain : Sebagai gelar kehormatan bagi barang-barang yang dianggap kramat, gelar kehormatan untuk orang-orang tua pada umumnya dan gelar yang diberikan oleh masyarakat kepada seorang ahli agama Islam yang memiliki atau yang menjadi pimpinan pesantren dan mengajar kitab-kitab Islam klasik kepada para santri. Selain gelar kyai, ia juga disebut dengan orang alim (orang yang dalam pengetahuan keislamanya).

Dalam sebuah pesantren, Kyai tidak hanya menjadi pondasi kelangsungan sistem pendidikan pesantren, namun menjadi role model karakter dan nilai kehidupan pesantren.

Kedudukan dan pengaruh Kyai menempati tempat paling tinggi; yakni keluhuran budi dan keluasan ilmu, penguasaan ilmu agama sekaligus cerminan pengejawantahan kehidupan agamis.

2) Santri

Santri merupakan komponen penting dalam sebuah pondok pesantren. Menurut KBBI, santri berati orang yang mendalami agama Islam, Orang yang beribadat dengan sungguh-sungguh (orang yang sholeh), dan orang yang mendalami 
pengajiannya dalam agama islam dengan berguru ke temoat yang jauh speerti pesantren dan lain sebagainya.

Nurcholish Madjid juga memiliki pendapat berbeda. Dalam pandangannya asal usul kata "Santri" dapat dilihat dari dua pendapat. Pertama, pendapat yang mengatakan bahwa "Santri" berasal dari kata "sastri", sebuah kata dari bahasa Sansekerta yang artinya melek huruf. Pendapat ini menurut Nurcholish Madjid didasarkan atas kaum santri kelas literary bagi orang Jawa yang berusaha mendalami agama melalui kitab-kitab bertulisan dan berbahasa Arab.

Santri adalah pelaku utama, orang yang menempuh kegiatan pemdidikan dalam pondok pesantren. Menurut tradisi pesantren sendiri, terdapat dua jenis kelompok santri yaitu : 1) santri Mukim, yaitu santri yang berasal dari daerah jauh dan menetap dalam kelompok pesantren. Santri mukim yang paling lama tinggal di pesantren biasanya memegang tanggung jawab untuk mengurusi kepentingan pesantren sehari-hari,mereka juga memikul tanggung jawab mengajar santri-santri muda tentang kitab-kitab dasar dan menengah. 2) Santri Kalong yang merupakan santri yang berasal dari desa-desa disekeliling pesantren, yang biasanya tidak menetap di pesantren. Untuk mengikuti pelajaranya di pesantren, mereka bolakbalik (nglaju) dari rumahnya sendiri.

3) Masjid

Secara harfiah, kata masjid berasal dari kata sajada-yasjudu-masjidan (tempat sujud). Gazalba (1994) menguraikan tentang masjid bahwa dilihat dari segi harfiah masjid memanglah tepat sembahyang.

Dalam sebuah pondok pesantren, Masjid menempati posisi penting sebagai sebuah pusat pendidikan dan tradisi pesantren. Masjid ini berfungsi sebagai manifestasi universalisme dari system pendidikan islam tradisional. Sejarah pentingnya masjid sebagai pusat pendidikan Islam sudah dimulai sejak jama Nabi. Kaum muslim menggunakan masjid sebagai tempat ibadah, tempat pertemuan, pusat pendidikan dan kebudayaan, aktivitas administrasi, sosial dan kultural.

Di lingkungan pesantren, fungsi masjid sangatlah vital. Fungsi utamanya adalah untuk penyelenggaraan sholat lima waktu. Pembiasaan sholat berjamaah bertempat di masjid pesantren. Selain itu, masjid juga berfungsi sebagai majelis ilmu. Kyai memberikan nasehat dan ilmu mengenai keagamaan kepada santri di masjid. Yang tidak kalah pentingnya, masjid juga sebagai tempat pembelajaran Al-Qur'an bagi para santri, baik belajar membaca secara morattal atau membaca indah dengan lagu.

Selain menjadi tempat ibadah dan menimba ilmu, masjid juga merupakan sarana sosialisasi bagi para santri. Pada waktu-waktu senggang, atau pada saat-saat menunggu datangnya waktu shalat berjamaah, sebagian santri memanfaatkan masjid sebagai sarana diskusi, tukar informasi dan atupun bercengkrama memperbincangkan kehidupan mereka di pesantren. Dengan adanya komunikasi ini, terbentuk ukhuwwah atau rasa persaudaraan yang erat di antara santri.

4) Pondok

Secara etimologis, kata pondok sendiri diambil dari bahasa arab yaitu funduq (

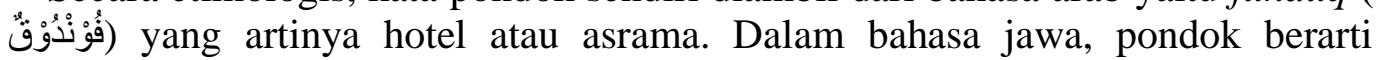
madrasah atau asrama yang digunakan untuk mengaji dan belajar agama Islam.

Secara istilah, pondok pesantren adalah tempat pendidikan yang menyelenggarakan kegiatan pembelajaran agama Islam bagi santri, yang diasuh oleh Kyai yang tinggal atau mukim bersama-sama dalam satu lokasi.

Pondok sendiri merupakan sebuah bangunan asrama pendidikan Islam tradisional. Disini santri tinggal bersama dengan kyai dan uztadz yang membimbing santri setiap hari. Umumnya pondok adalah sebuah lingkungan yang dimiliki oleh Kyai secara pribadi. 
Pondok adalah lingkungan yang sengaja diciptakan untuk mendidik santri. Sarana apapun, gerakan atau disiplin yang ada dalam pondok, semuanya untuk mendidik santri, bukan untuk santai, rekreasi atau hura-hura. Dengan demikian segala sesuatu yang ada dalam pondok harus mempunyai nilai pendidikan.

Dilihat dari bentuk bangunan, bangunan pondok pesantren wujudnya beraneka ragam. Ada jenis pesantren yang pondok santrinya berupa tobong atau bangunan kamar kecil sederhana yang di tempati oleh beberapa santri sekaligus. Ada juga jenis pesantren modern dengan bangunan gedung dan lebih modern. Meskipun memiliki bentuk bangunan fisik yang berbeda, namun terdapat konsep yang sama, yakni satu kamar akan ditempati oleh beberapa santri secara bersamaan.

Dalam pesantren besar biasanya terdiri dari beberapa blok tempat tinggal yang diorganisir oleh seorang seksi. Pondok tempat tinggal santri wanita biasanya dipisahkan dengan pondok santri laki-laki, selain dipisahkan oleh rumah kyai dan keluarganya, juga oleh masjid dan bangunan-bangunan lain. Komplek pesantren biasanya dikelilingi oleh tembok agar para santri dapat diawasi keluar dan masuknya sesuai dengan peraturan yang berlaku.

Umumnya pesantren membuat pondok bagi santrinya dikarenakan beberapa alasan, yakni : 1) kyai yang terkenal akan luasnya ilmu agama, menarik minat santri yang asalnya dari tempat jauh. Karenanya, santri memerlukan tempat tinggal sementara untuk belajar seluruh ilmu agama (yang membutuhkan waktu tidak sebentar); 2) sebagian besar peasntren berdiri di loaksi yang jauh dari pemukiman, sehingga tidak ada fasilitas menginap untuk santri. Dengan demikian, perlu pondok khusus untuk santri tinggal; dan 3) adanya hubungan batin antara Kyai dan santri, Kyai menganggap santri sebagai anak yang harus dilindungi dan diperhatikan.

System pondok bukan saja merupakan komponen paling penting dari tradisi pesantren. Walaupun keadaan pondok sangat sederhana, para santri dapat belajar dengan lingkungan sosial yang baru. Dengan sistem pondok ini juga, santri dibimbing secara intensif untuk mendapatkan ilmu agama dan mengaplikasikan ajaran mengenai karakter agamis yang positif dalam lingkungan yang kondusif.

5) Pengajaran kitab-kitab islam klasik

Sejak jaman dahulu, pesantren terkenal akan keilmuan agama yang mumpuni. Yang utama adalah pelajaran kitab klasik atau yang biasa dikenal dengan istilah kitab kuning. Saat ini, banyak pesantren modern yang mulai menggunakan pelajaran umum lain, namun cirri khas pelajarna kitab klasik ini masih di berikan.

Keseluruhan kitab-kitab klasik yang diajarkan di pesantren dapat digolongkan dalam delapan kelompok diantaranya : Nahwu (syntax) dan saraf (morfologi), Fiqih, Ushul fiqih, Hadits, Tafsir, Tauhid, Tasawuf dan etika, dam cabang-cabang lain seperti tarikh dan balaghah

Sistem pengajaran kitab klasik ini pun khas. Adapun cara mereka menyampaikan dan mengevaluasi sejauh mana materi dapat dikuasai oleh para santri ada empat model yaitu : 1) Metode Sorogan, atau mentoring system, dimana santri diajak memahami kandungan kitab kuning secara perlahan-lahan, detail, teliti mengikuti pikiran dan konsep-konsep yang termuat dalam kitab dari kata per kata; 2) metode Bandongan, berupa pengkajian kitab-kitab induk dimana seorang kyai atau ustadz membacakan dan menjabarkan isi kandungan kitab kuning sementara para santri mendengarkan dan member makna. 3) metode Musyawarah atau diskusi, diman a para santri dianjurkan untuk menelaah, memahami suatu topic atau masalah yang terdapat pada masing-masing kitab kuning. 4) metode Muhafadhoh atau hafalan, yaitu kegiatan belajara santri menghafal materi pelajaran secara teratur dengan menghadap kyai atau ustadz. 
Metode hafalan sangat efektif untuk memelihara daya ingat santri terhadap materi yang dipelajarinya

d. Proses dan Kegiatan Pendidikan Pesantren

Dalam proses pembentukan akhlak, Mukni'ah (2011) menyatakan bahwa ciri khas orang yang beriman adalah indah perangainya dan santun tutur katanya, tegar, dan teguh pendirian (tidak terombang-ambing), mengayomi atau melindungi sesama, mengajarkan buah amal yang dapat dinikmati oleh lingkungan. Kegiatan pondok pesantren merupakan latihan dan pengamalan dari proses pembelajaran pembentukan akhlak yang baik.

Kegiatan yang ada di dalam pondok pesantren merupakan kegiatan pelatihan untuk beribadah. Kegiatan beribadah ini didasarkan dengan prinsip implementasi pengalaman atas rukun iman dan penjabaran makna bagi kehidupan nyata misalnya: shalat, puasa, zakat dll.

Kehidupan santri di pondok pesantren yang jauh dari orang tua, akan membentuk santri yang mandiri dalam mengatur kehidupannya sendiri. Menurut Hidayat (2016) kemandirian anak dibentuk oleh beberapa faktor, yaitu : Rasa percaya diri, kebiasaan hidup, dan disiplin,

Semua kegiatan yang dilakukan dalam lingkungan pesantren dimaksudkan untuk mengembangkan ketrampilan agar santri memiliki ketrampilan dan disiplin yang akan menumbuhkan sikap, mental yang jujur, ikhlas, sabar, tegar dan berani.

Dari teori dan pemaparan di atas, penulis menarik kesimpulan bahwa pola asuh yang dilaksanakan di pesantren ditujukan untuk pembentukan akhlakul karimah yang sesuai dengan nilai-nilai ajaran agama Islam. Di dalam lingkungan pondok pesantren, pembelajaran bukan hanya mengenai belajar teori atau kitab, namun pembelajaran juga dilakukan melalui pola asuh untuk menciptakan karakter baik sesuai yang diharapkan. Keteladanan disertai disiplin ditujukan untuk membentuk suasana lingkungan pesantren yang kondusif. Dengan hal ini, santri akan mendapatkan karakter baru sesuai yang di harapkan.

Jika kita merujuk pada teori pola asuh, jenis pola asuh yang di terapkan di pesantren adalah jenis pola asuh demokratis. Dimana santri diberikan kebebasan namun tetap bertanggung jawab terhadap segala yang dilakukan. Hal ini ditujukan agar santri mempunyai sikap menghargai dan menghormati pendapat orang lain, perhatian kepada sesama serta mempunya karkater baik yang bisa bekerja sama dan bertanggung jawab dan pantang menyerah dalam menghadapi segala jenis situasi.

\section{KESIMPULAN}

Sebagai sebuah instituasi pendidikan yang memegang peran ganda, sebagai pelaksana pendidikan formal dan informal, Pondok Pesantren tidak hanya mengedepankan mengenai keilmuan, namunjuga pembentukan karakter Islami pada santrinya.

Pola asuh yang diterapkan pada kebanyakan pondok pesantren adalah pola asuh demokratis yang di kombinasikan dengan otoriter. Hal ini sejalan dengan tujuan untuk membina santri dalam mengembangkan karakter positif, berani, bertanggung jawab, menghormati dan menghargai pendapat orang lain, mau bekerja sama dan santun, namun tetap memahami dan menghormati peraturan yang ada di pondok pesantren. Pengembangan karakter ini dilakukan menyatu dengan pelaksanaan kegiatan harian santri, baik yang bersifat kegamaan, interaksi sosial dengan kyai, ustadz atau santri lain dan kegiatan pendidikan formal. Kyai dan Nyai menjadi role model sebagai bentuk pengejawantahan karakter positif yang bencerminkan nilai karakter agamis. Dalam keseharian, pembinaan sosial santri di lakukan dalam bentuk pola demokratis dan bertanggung jawab. Hal ini ditunjukkan dengan adanya penerapan tindakan disiplin yang dibuat oleh pengasuh dan di lakukan oleh santri secara mandiri. Pola asuh yang demokratis ini akan mendorong perkembangan santri untuk berkepribadian yang positif Di sisi 
lain, pola bertanggung jawab tampak dengan adanya pemberlakukan sanksi ketika santri melakukan pelanggaran.

\section{DAFTAR PUSTAKA}

Abuddin, Nata. (2001). Pemikiran Para Tokoh Pendidikan Islam. Jakarta : PT. Rineka Cipta.

Ali, Kemas Mas'ud, Imtihana, Islamil Aida, Zaini Fajri, Herman. (2017) Penerapan Pola Asuh

Terhadap Santri di Pondok Pesantren Al - Amalul Khair Palembang. Jurnal

Pendidikan Agama Islam, from : http://jurnal.radenfatah.ac.id

Ambarwati, Ina. (2018). Pola Asuh dan Pembentukan Karakter Santri di Pondok Pesantren.

Journal of Islamic Guidance and Counseling. Vol. 2,

from:https://jigc.dakwah.uinjambi.ac.id

Arifin, Muzayyin. (2003). Filsafat Pendidikan Islam. Jakarta : Bumi Aksara.

Damopolii, Muljono. (2011) Pesantren Modern IMMIM Pencetak Muslim Modern (Edisi 1). Jakarta: Rajawali Pers.

Departemen Agama RI, Direktorat Jenderal Kelembagaan Agama Islam. (2003). Pondok Pesantren dan Madrasah Diniyah Pertumbuhan dan Perkembangannya. Jakarta : Departemen Agama RI.

Diponegoro, Ahmad. M. (2005). Afek dan Kepuasan Hidup Santri. Jurnal Psikologi Islam I. (2), 107-118. Yogyakarta: PP Asosiasi Psikologi Islami.

Gunarsa, Singgih. (1990). Dasar dan Teori Perkembangan Anak. Jakarta : PT BPK Gunung Mulia.

Hidayat, Syarif. (2016). Perkembangan Peserta Didik. Tangerang : PT Pustaka Mandiri.

Hidayat, Syarif. (2019). Teori, Proses dan Konteks Sosial Budaya Pendidikan. Tangerang : PT Pustaka Mandiri.

Mahmud. (2011). Metode Penelitian Pendidikan. Bandung : CV Pustaka Setia.

Mastuhu. (1994). Dinamika Sistem Pendidikan Pesantren: Suatu Kajian Tentang Unsur dan Nilai Sistem Pendidikan Pesantren. Jakarta: INIS.

Mestika Zed. (2008). Metode Penelitian Kepustakaan. Jakarta : Yayasan Obor Indonesia.

Usman, Muh. Idris. (2013). Pesantren Sebagai Lembaga Pendidikan Islam. Jurnal Al Hikmah Vol. XIV Nomor 1, from : http://journal.uin-alauddin.ac.id/

Mukni'ah. (2011). Materi Pendidikan Agama Islam Untuk Perguruan Tinggi Umum. Jogjakarta: Ar-Ruzz Media.

Nata, Abuddin. (2001). Pemikiran Para Tokoh Pendidikan Islam. Jakarta : PT. Rineka Cipta.

Qomar, Mujamil. (2007). Pesantren Dari Transformasi Metodologi Menuju Demokratisasi Institusi. Jakarta: Erlangga.

Shihab, Alwi. (2002). Islam Inklusif. Bandung: Mizan.

Shochib, Moh. (2010). Pola Asuh Orang Tua (Dalam Membantu Anak Mengembangkan Disiplin Diri Sebagai Pribadi Yang Berkarakter). Jakarta : Rineka Cipta .

Soetjiningsih. (2010). Tumbuh Kembang Remaja dan Permasalahannya. Jakarta : Sagung Seto. Sriyatun, Arif Budi Witarto, Mega Trishuta Pathiassana, Moh. Kodri. (2020). Strategi Pembinaan Akhlak Santri di Pondok Pesantren Internasional Dea Malela. Jurnal Tambora. Vol. 4. No. 2A. from : http://jurnal.uts.ac.id.

Suryadi, Maslahatun Nikmah. (2009). Pola Pembinaan Santri dalam Pengendalian Prilaku Menyimpang di Pondok Pesantren Ar-Risalah Kota Jember. Islamic Counseling : Jurnal Bimbingan dan Konseling Islam. Vol. 3, No. 2 (hal 139 - 154). From : https://www.researchgate.net/publication/337998310

Susanto, Happy. (2017) Perubahan Perilaku Santri (Studi Kasus Alumni Pondok Pesantren Salafiyah Di Desa Langkap Kecamatan Besuki Kabupaten Situbondo). Istawa Jurnal Pendidikan Islam 2 (1) : 1, from

Syafe'i, Imam. (2017) Pondok Pesantren : Lembaga Pendidikan Pembentukan Karakter. AlTadzkiyyah: Jurnal Pendidikan Islam, Volume 8. Mei 2017 E-ISSN: 2528-247, from : http://ejournal.radenintan.ac.id/ 